\title{
How do Governments Fare about Redistribution? New Evidence on the Political Economy of Redistribution
}

\author{
Fabio Padovano \\ Francesco Scervini \\ Gilberto Turati
}

CESIFO WORKING PAPER NO. 6137

CATEgory 2: Public CHOICE

OCTOBER 2016

An electronic version of the paper may be downloaded

- from the SSRN website:

- from the RePEc website:

WWw.SSRN.com

- from the CESifo website:

www.RePEc.org

www.CESifo-group.org/wp

\section{CESifo}




\title{
How do Governments Fare about Redistribution? New Evidence on the Political Economy of Redistribution
}

\begin{abstract}
We examine whether and to what extent political institutions explain different performances in income redistribution across countries. In particular, we first review available sources of data and measures of income redistribution, discussing the pros and cons of each one. Second, we outline a conceptual framework that distinguishes traditional demand side explanations of redistribution from resources and instruments, as well as supply side factors. We then provide empirical evidence on the association between these different factors and the observed degree of redistribution. Our analysis supports the view that - for a given demand of redistribution political (and economic) institutions contribute to explain differences across countries in the observed degree of redistribution.
\end{abstract}

JEL-Codes: D780, I380, H530, H110.

Keywords: redistribution, ex ante and ex post Gini coefficients, political and economic institutions.

Fabio Padovano
DSP, University Roma Tre / Italy
padovano@uniroma3.it

Fabio Padovano padovano@uniroma3.it 


\section{Introduction}

According to the traditional welfare economics approach (e.g., Musgrave, 1959), government intervention in market economies can be justified on two different grounds: first, from an efficiency viewpoint, whenever markets fail to reach Pareto optimal allocations; second, from an equity viewpoint, whenever the distribution of resources stemming from private markets is judged as inequitable by members of the society. But while government failures have posed serious doubts on the ability of public authorities to improve inefficient market outcomes, casting shadows on justifying government intervention from the efficiency standpoint, the search for a more equitable distribution of resources still represents an important goal for policy makers (in this sense, also Tullock, 1983). Yet, despite its importance and a large literature mapping the evolution of income and earnings inequality, we do have a poor knowledge on the redistributive performance of governments around the world: How much do governments redistribute? How do they compare in terms of redistribution? How much do ex-ante (market) inequality differ from ex-post (after government intervention) inequality?

Recent empirical analyses suggest that differences across Western economies in terms of the redistributive performance are large and somewhat unexpected. For instance, among the nine western democracies considered in their work (Belgium, France, Germany, Great Britain, Italy, the Netherlands, Norway, Sweden and the United States), Lefranc et al. (2008) show that Italy and the United States are the most unequal in terms of both outcomes and opportunities. The result is certainly striking given the relative size of the welfare spending in the two countries, and the different degrees of progressivity of their tax systems: one would expect Italy to achieve a higher amount of redistribution than the United States. Similar considerations could be made about France and the United Kingdom, two countries with similar redistributive performances, but with quite different welfare states in terms of size and structure (mainly universalistic the French one, more prone to means testing the British). Other studies, based on different methodologies and definitions of inequalities, reach similar results (Gottschalk and Smeeding, 1997; Roemer et al., 2003). The question is: why?

From a theoretical viewpoint, Okun's famous 'leaky bucket experiment' is one of the early attempts in shaping our understanding of the difficulties governments face in redistributing resources, and might offer an explanation. When the government aims at transferring income from rich to poor individuals '...money must be carried 
[...] in a leaky bucket. Some of it will simply disappear in transit, so the poor will not receive all the money that is taken from the rich' (Okun, 1975, p. 91). Okun attributed those leakages to just two important problems: the administrative costs of taxing and transferring resources, and the disincentive effects in the supply of labour and investments in both physical and human capital. ${ }^{1}$ But these are not the only holes in the bucket one might think of.

Standard public choice explanations of coercive redistribution (Romer, 1975; Meltzer and Richard 1981, 1983) emphasize the role of voters, in particular the median voter, generally predicting that the middle class plays a pivotal role in redistributive policies. However, recent empirical tests based on the Luxembourg Income Survey dataset, do not support this 'median voter hypothesis'. Milanovic (2000) and Scervini (2012) found not only that the net gains from redistribution for the middle class are negligible, but also that the link between income and redistribution is lower than for any other income class. Moreover, the amount of redistribution targeted to the middle class is lower in more asymmetric societies, a result in strong contrast with the logic of the median voter theorem. If voters' preferences for redistribution (the demand side) do not explain the amount of resources that governments devote to the reduction of inequalities, it is to the influence of the supply side of the political market, namely to political institutions, that the analysis of the redistributive performance of different countries must focus on.

This is the issue we tackle in the paper. The main intuition is that demand for redistribution is driven by voters' preferences, but policy outcomes stem from the interaction of this demand with the supply of redistribution via political institutions and the resulting rent-seeking behavior, government fractionalization, composition of the public budget, and so on. To this end, we first systematically review the available data to measure redistribution, and then provide an empirical analysis of the relationship between these available measures and the variables characterizing different political institutions across countries. Though we are not able to establish any strong causal links, our findings clearly suggest that the supply side (i.e., political and economic institutions) is important to explain how governments fare in terms of redistribution.

\footnotetext{
${ }^{1}$ See Hillman (2009, pp. 503-507) for a formal treatment of the leaky bucket in redistribution. See also Ballard (1988) and Browning and Johnson (1984).
} 
The remainder of the paper is organized as follows. Section 2 reviews and discusses the available measures of redistribution, while section 3 sketches a conceptual framework in which demand for redistribution has to meet with available political and economic institutions. In section 4 we discuss the empirical strategy and the estimates. Section 5 concludes.

\section{The first step: measuring redistribution}

While a number of studies have been devoted to the analysis of the dynamics of earnings and income inequality (e.g., Gottshalk and Smeeding, 1997), and - more recently - to the polarization observed in top incomes, especially in Anglo-Saxon countries (e.g., Atkinson et al., 2011, Piketty and Saez, 2013), much less work can be found on the correlates of income re-distribution. A main explanation is that, despite the two concepts are clearly related, redistribution poses more serious problems than inequality in terms of measurement. The most typical measure is the difference between income distribution before any government intervention (typically, the market income) and income distribution after government policies have been implemented. In the literature, income distribution is usually proxied by measures of the incidence of poverty, the share of aggregate income received by the bottom quintile of household units, and more generally by the Gini coefficient. Considering the Gini coefficient, most of the available microdata (typically used for the analysis of income dynamics and inequality) allow the computation of the ex post Gini on disposable income only. In order to obtain the ex ante Gini on market income, one needs to rely on microsimulation models, which require a profound knowledge of tax and spending rules for each country in each year, and typically account for cash transfers and income taxes only. This involves a bias in the measure of redistribution, as there is evidence that both policy tools generate redistributive effects (e.g., Besley and Coate, 1991, and, on different country sets, Mahler and Jesuit, 2006; Sonedda and Turati, 2005). Hence most contributions that study income redistribution typically focus on one country or on a selected group of countries, and - more importantly on a specific policy or transfer program (e.g., Danziger et al., 1981, for an old review). This is largely unsatisfactory if one is interested in the overall redistributive performance of governments across the world.

The difference between ex-ante and ex-post Gini coefficients presents another important limitation according to Danziger et al. (1981), which concerns the 
definition of the counterfactual: what would have been the distribution of ex ante income in the absence of any government transfers and taxes? An accurate definition of the ex ante income would require considering the full set of general equilibrium changes in relative prices and incomes in the hypothetical case where all governments' programs had been removed. According to Danziger et al. (1981), in such a scenario pre-transfers income would have been less unequally distributed, which implies that the difference in Gini indices is likely to be an (unbiased) upper bound estimate of the degree of redistribution. ${ }^{2}$ This critique to measuring redistribution has been disputed by Milanovic (2010). He argues that existing welfare regimes (and their generosity) do not emerge spontaneously, but are the result of the evolution of political processes within different nations. When people vote for a given regime, they take into account both the eligibility rules and the change in behaviours entailed by these rules. Finally, it is important to note that the measure of redistribution based on the difference between the Gini indices fits well also with the encompassing character of Okun's idea of the leaky bucket: if one wants to understand what are the political factors responsible for drilling the holes in the bucket, one needs this very simple measure of redistribution, including also the disincentive effects implied by government policies.

In practical terms, applied researchers can rely on at least three sources of data, which differ widely in terms of quality and cross-country comparability. The most comprehensive effort to produce cross-country comparable data on income inequality and redistribution have been made by the Lisdatacenter (former Luxembourg Income Study, LIS), which collects country-specific household surveys from high- and middle-income countries and harmonize them in order to provide individual-specific information about income, labour market and socio-economic characteristics. It provides highly comparable microdata, but only on a very small set of countries and years. In particular, Lisdatacenter provides a strongly unbalanced panel of less than 50 countries starting from 1967 up to 2013, for a total of about 250 observations, with most of the countries having less than 10 observations, not necessarily in consecutive years. Most of the countries included are OECD countries, but the sample includes also observations from other countries, such as Georgia, Guatemala and Taiwan. Relying on these microdata, one can compute several inequality indicators on different definitions of income. In particular, following the

\footnotetext{
${ }^{2}$ Under the hypothesis that the behavioral response to changes in welfare provision be approximately the same across countries.
} 
definitions of income in Milanovic (2000), we compute here ex-ante and ex-post Gini coefficients, and the mean/median ratio. Alternatively, SWIID (Solt, forthcoming) relies on the WIID dataset (UNU-WIDER, 2015) and fills the missing information in WIID using multiple imputation techniques, validating it using the higher-quality LIS data. While WIID only collects data from very heterogeneous sources, classifying them according to quality, units of analysis, population coverage and so on, the standardized version SWIID intends to provide a fully comparable panel of country/year Gini coefficients on both market and net incomes. With respect to LIS, the great advantage of SWIID is the wide coverage: it is still an unbalanced panel, but includes 169 countries from 1960 to 2013, for a total of 4627 country/year cells. The drawbacks are the availability of Gini coefficients on market and net incomes only, and the fact that - since data are estimated - one needs to take into account the multiple imputation in order to account for the precision of estimations. Finally, the OECD Income Distribution Database (IDD) provides an unbalanced panel of comparable data on inequality in OECD countries. Differently from LIS, IDD does not provide microdata, but computes and makes available several inequality measures (Gini coefficients on market, gross and net incomes, and five different decile ratios). The main drawbacks are that the country coverage is very limited (only 32 countries are included) and the panel is severely unbalanced: most of the observations relates to Canada and Finland, with 36 years and 27 years covered, respectively; less than 5 observations are available for Chile, Japan, and Australia. Time span ranges from 1976 to 2014, for a total of 221 observations.

Table 1 compares ex-ante and ex-post Gini on the small common sample of country/year across the three sources, while Figures 1-2 plot the pairwise comparisons. The Gini coefficients on net incomes (ex-post Gini) are very similar in the three datasets, while the Gini coefficients on market/gross incomes (ex-ante Gini) are much smaller for LIS. This is due to the fact that, in line with Milanovic (2000), the definition of gross income in this case includes public pension transfers, on the ground that pensions are mostly deferred income rather than redistribution. Consistently, market income inequality in the OECD and SWIID are virtually identical. In the light of the small differences between IDD and SWIID, on the fact that the sample of countries in IDD is very similar to that in LIS and on the results of the regressions presented in table 4 (see section 4.3 for more details), we decided to exclude IDD from our analysis below for the sake of parsimony, and to focus only on LIS and SWIID in order to account for the differences in the definition of income and in the sample of countries. 
Table 2 shows descriptive statistics for these two data sources. Notice that, because of the multiple imputation procedure, SWIID means are estimated (standard errors presented in column VIII for Gini coefficients and absolute redistribution). Table 3 presents the variance decomposition of the Gini coefficients in the LIS sample. As expected, it emerges that most of the variance of both inequality and redistribution is between countries, while within country variation is relatively small.

\section{Second step: the conceptual framework}

The empirical literature on the correlates of the degree of redistribution has clearly suffered from both the lack of comparable data and the quality of available data. Most of the papers are based on the LIS data (Milanovic, 2000; Tanninen and Tuomala, 2001; Mahler and Jesuit, 2006; Scervini 2012; Feld and Schnellenbach, 2014). Only recently, scholars have started looking at SWIID data (e.g., Sturm and De Haan, 2015).As for the variables that might influence the degree of redistribution, the literature has focused mainly on the demand side. Alesina and Giuliano (2011) survey a number of variables affecting preferences for redistribution, including for instance the perceived social mobility, religious beliefs and political ideology. Like for the measure of redistribution, however, the choice of variables in the empirical literature is largely data driven, since also the regressors must be available for the same country/year combinations characterizing the difference in the Gini coefficients. A first variable which is often used is a measure of ex ante inequality, on the ground that greater inequality in market incomes leads voters to ask for more redistribution; this variable is generally found to be significantly associated with more redistribution (e.g., Tanninen and Tuomala, 2001; Scervini, 2012). ${ }^{3}$ Voters' preferences can also be proxied by the dependency ratio (considering both the young and the elderly), but this variable turn out to be insignificant in the work by, e.g., Tanninen and Tuomala (2001) and Mahler and Jesuit (2006); or the unemployment rate, which turns out to be significant in Mahler and Jesuit (2006). Sturm and De Haan (2015) study the role of ethno-linguistic fractionalization, on the premise that in more fractionalized countries people will vote for less redistribution. Their findings

\footnotetext{
${ }^{3}$ This result is in contrast with De Mello and Tiongson (2003), who however focus on 'redistributive transfers' to assess whether more unequal societies redistribute more. This difference suggests that transfers per se do not need to be redistributive, and the whole array of redistributive devices available to governments must be considered when trying to assess redistribution.
} 
suggest that this result is conditional to the level of economic freedom: capitalist countries have a low degree of fractionalization and redistribute more. Still on the demand side, Milanovic (2000) and Scervini (2012) test the role of the preferences of the 'median voter'. Their findings suggest that the median voter does not seem to affect redistribution, as the middle class appears to obtain fiscal gains lower than those accruing to poorer individuals.

But the demand for redistribution is just one side of the coin. Demand in fact needs to be matched with the supply of redistribution, which includes both the political and economic institutions that affect redistributive choices (the political regime, the voting mechanism, ...), and the instruments and resources available for redistribution (the structure of the personal income tax, the composition of the public budget in terms of both revenue and spending, ...). Of course, all these institutions and instruments may not be efficient in redistributing resources, drilling holes in Okun's bucket.

Using this conceptual framework, it is easy for instance to classify government employment out of total employment, a variable used by Tanninen and Tuomala (2001) in their analysis, as an equilibrium policy measure which can affect redistribution, given both the demand and the supply of redistribution. But also to consider standard controls like per capita income and GDP growth as measures for the available resources which can be distributed (e.g., Scervini, 2012; Mahler and Jesuit, 2006).

As for the political variables, one should distinguish a time frame in which political institutions can be considered as given from a time frame in which the demand for redistribution may even modify these institutions. In the short run, for a given set of political institutions, the demand of redistribution can affect - for instance - the political orientation of the government, as well as government fragmentation. In a longer run perspective, however, the demand for redistribution can impact for instance on the democratization process and on the choice between presidential versus parliamentary regimes, modifying political institutions to make them more effective in achieving a given redistributive goal (e.g., Boix, 2003; Acemoglu and Robinson, 2015; Aidt and Franck, 2015). All these variables have been used by the literature, but most of them have not turned out statistically significant in regressions considering the degree of redistribution; the only notable exception is a variable identifying presidential regimes, which appear to negatively affect redistribution (e.g., Scervini, 2012). Mahler and Jesuit (2006) attribute a role also to voter turnout, recognizing welfare states and redistribution as the results of conflicts 
between class-related interest groups. In their empirical analysis, the higher is the turnout, the higher are social conflicts and the degree of redistribution. Feld and Schnellenbach (2014) consider how decentralization of revenue and spending powers influence redistribution. They find a robust negative relation between tax autonomy and total redistribution, which however turns positive once they take into account fiscal equalization schemes. They interpret this evidence as the result of the role played by federations in achieving redistribution via intergovernmental transfers; by that, for the first time they explicitly focus on political institutions as a fundamental determinant of the degree of redistribution achieved by one country.

Finally, also economic institutions might have a role in shaping the degree of redistribution. Mahler and Jesuit (2006) consider, for instance, the labour market institutions, like the degree of 'corporatism' in institutional arrangements and the unionization rate. Regression analysis confirms that the degree of corporatism is statistically significant, and it increases redistribution. Yet, economic institutions too can be affected by demand for redistribution in the long run.

\section{Third step: regression analysis}

\subsection{The empirical strategy}

We apply the conceptual framework defined above in order to understand whether and how political institutions play a role in determining the actual degree of redistribution in a given country, drilling additional holes in Okun's bucket. Following the literature, our dependent variable is the difference between the Gini $e x$

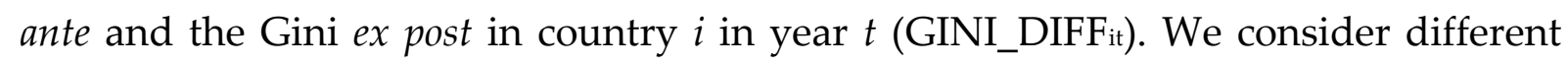
group of explanatory variables: first, we examine the impact of variables related to the demand for redistribution only $(\mathrm{X})$; second, we augment the baseline model by taking into account political and economic institutions, the main supply side variables for redistribution $(\mathrm{W})$; third, we augment the model by testing the role played by the main instrument for redistribution, namely public spending, and then consider also the available resources for redistribution, including also public deficit and debt, and the composition of the public budget (Z). Finally, we check whether these possible correlates of redistribution may be associated with ex ante inequality, exploring the hypothesis that the government can redistribute resources ex ante via a reduction of market income inequalities. Equation [1] represents our general model: 


$$
\text { GINI_DIFF } F_{i t}=\alpha+\sum_{j} \beta_{j} X_{j i t}+\sum_{k} \beta_{k} Z_{k i t}+\sum_{h} \beta_{h} W_{h i t}+\varepsilon_{i t}
$$

where $\varepsilon_{\text {it }}$ is a stochastic disturbance. To account for the likely presence of heteroskedasticity and the correlation across periods of time in the errors, standard errors are clustered by country in all our estimates. We also investigate the impact of clustering on our estimates in the baseline model, by using also non clustered standard errors, as well as the more traditional Panel Corrected Standard Errors proposed by Beck and Katz (1995) and widely used in the political science literature. Notice that, starting from the conceptual scheme defined above and consistently with the descriptive statistics in Table 3, country fixed effects are not included in the model, since most institutions change only in the long run. However, we include in all models also macro-region fixed effects for Africa, Americas, Asia, Europe, MiddleEast and Oceania. Of course, there are several reasons why the evolution of political and economic institutions might be similar for countries in the same macro-region; hence, also these models are likely to suffer from the same low variability detected at the country level. Additionally, time fixed effects are included only when using SWIID data, i.e., when the sample size is sufficiently large and the panel structure is sufficiently long and complete. As for the sample size, we run the model considering different sources of data first using all available observations for each source, and then restricting the samples to match the year/country data available in the LIS sample, as it is the most limited, but also the one with the highest quality.

Despite the efforts in properly modelling the error process, causal inference is problematic for at least two issues. One main issue, , is endogeneity and reverse causality, especially for the instruments and the resources for redistribution, which in the short run can be affected by the degree of inequality, and the consequent demand for redistribution. It is definitely less problematic for political and economic institutions, which can be affected by the degree of inequality only in the long run. The second issue is parameter heterogeneity, a common problem for cross-country macro regressions (e.g., Temple, 1999). For instance, the way in which corruption affects redistribution may vary from one country to another, despite the inclusion in the model of a number of controls. For both reasons, we take a conservative approach and interpret the present analysis as a search for robust ceteris paribus correlations. 


\subsection{Data and definitions for controls}

We have already discussed data and definitions for the dependent variable in previous section 2. In order to study the role of supply side variables on redistribution we now need to find for all country/year for which a measure of redistribution is available the corresponding controls. Again, this is also not an easy task. Political data come from the PolityIV (Marshall et al, 2016) dataset and the World Bank Dataset on Political Institutions (DPI) (Beck et al, 2001). In particular, the Polity2 is a composite index of democracy released by the PolityIV project that ranges between -10 (least democratic) and +10 (most democratic countries), according to a wide set of institutional features, such as competitiveness and openness of executive recruitment, the constraints on the chief executive, the competitiveness of political participation and so on. The DPI includes more detailed indicators of the political framework, such as the political orientation of the government in office, the electoral system (proportional vs. majority), or the institutional design (presidential vs. parliamentary). Another source of qualitative institutional characteristics of a country is the Fraser Institute (Gwartney et al, 2015), that releases, on a yearly basis, several synthetic indices of economic freedom, divided in five branches (size of government, legal system and property rights, sound money, freedom to trade internationally, and freedom from regulation), each one made up by several indicators. We include in our analysis indicators of freedom from corruption, freedom from regulation (as well as its components freedom from labour market regulation, freedom from credit market regulation, freedom from business regulation), and the size of government, proxied by the top marginal tax rate index. It is worth noting that all these measures assume that regulation and freedom are always in contrast, so that less regulation, lower taxes, smaller government lead to more freedom. Finally, we use the quantitative measures of public spending (total and by categories) and per capita GDP published by the World Bank World Development Indicators. Summary descriptive statistics for all the variables are in Table 2.

\subsection{Results}

\subsubsection{Demand side}

Table 4 shows our baseline analysis including only demand side variables. In particular, we consider the ex-ante Gini coefficient on market income and the ratio 
between mean and median market income as proxies of the preferences for redistribution. According to the standard Meltzer and Richard (1981, 1983) argument, for both variables we expect a positive relationship with redistribution: the more unequal the distribution, the higher the demand for redistribution should be. Results are consistent across the three sources (LIS, SWIID, OECD), both when using all the available data and a restricted sample featuring the country/year data available in the LIS. They are also consistent when different definitions for the standard errors are adopted, even though, as expected, clustering at the country level appears to be the most restrictive option. In particular, the coefficient on the Gini index provides support to the Meltzer and Richard traditional story: the more unequal the distribution, the higher the demand for redistribution. In line with Scervini (2012), however, the coefficient for the mean to median income ratio is consistently negative and significant; this result cannot be explained within the traditional Downsian approach, as it requires assuming, for instance, that richer individuals have more political power with respect to the other ones. A quite simple explanation is provided by Larcinese (2007), who argues that richer individuals are more likely to vote; hence, office-seeking candidates might target these individuals instead of the median voter when defining their platforms. Voter turnout becomes then relevant in explaining the observed degree of redistribution; what Larcinese (2007) does not take into account is the fact that different political institutions might affect voter participation (on this point see the evidence provided by, e.g., Blais et al, 2003).

Since results are much similar across samples and using different definitions for the standard errors, in the remainder of the analysis we cluster errors at the country level and compare LIS and SWIID data only. In Table 5 we augment the baseline model by including the size of the public sector, measured by the ratio of public spending to GDP. According to the traditional Meltzer and Richard approach the demand for redistribution should expand the size of the public sector more the more unequal is the distribution of market income. One would then expect a positive relationship between government size and redistribution. This seems to be indeed the case, since the coefficient is positive and statistically significant across all specifications, irrespective of the sample and of the data source used. Notice also that, when including this variable, the value of the coefficient for the ex-ante Gini index becomes smaller, a signal that this variable can be understood as an additional proxy for the demand of redistribution, albeit reasonably mediated by political institutions. 


\subsubsection{Supply side}

In Table 6 we start exploring the role of political institutions; in particular, we discuss the link between constitutional rules and redistribution, in line with Persson and Tabellini (2003). All previous results on the role of ex-ante inequality still hold controlling also for the institutional differences across countries, while public spending is now significant only in the SWIID sample, suggesting that public expenditure stems from the interaction between demand and supply of redistribution. First, the coefficient on the Polity 2 democracy index is always positive, but it is not always statistically significant, especially when using the LIS data, likely because of the sample of countries, which which is characterized by a low variability with respect to this variable. The result is largely in line with the inconclusive evidence stemming from the empirical literature reviewed in Acemoglu et al. (2015), and suggests once more a critique to the standard Meltzer and Richard's argument: extending electoral rights to the poorer segments of the society does not need to translate into pro-poor policies. On the contrary, the results on corruption are uncontroversial: more corruption is associated with less redistribution. Given the evidence of a high correlation between corruption and standard measures of the size of the informal economy (e.g., Buehn and Schneider, 2012), this covariate may also capture people's attitudes against redistribution, manifested by hiding a share of the tax base from the tax authorities. As for the government system, presidential regimes seem to redistribute less than parliamentary systems, a result which can be explained by considering the stricter separation of powers in presidential regimes compared to parliamentary systems, which reduces the room for collusion between rent-seeking politicians (Persson and Tabellini, 2003). An alternative explanation is that the form of government affect which, among the pro-rich and the pro-poor parties, will win the democratic contest over redistributive policies (Becher, 2015). Following on this line, we also find that a majoritarian voting system is associated with less redistribution, while the partisan orientation of the executive does not matter. These findings confirm the intuition of Becher (2015), which attributes importance to political institutions in shaping redistributive policies more than to the ideology of the parties. From a theoretical standpoint, under proportional representation, parties that represent different groups of citizens need to form coalitions in order to be able to implement policies; this will typically result in higher taxes, and in a larger public 
sector (e.g., Iversen and Soskice, 2006; Alesina and Glaeser, 2004; Persson and Tabellini, 2003, Austen-Smith, 2000).

In Table 7 we test the role of economic institutions, considering in particular the measures of regulation provided by the Fraser Institute. According to definitions, the measure for credit market regulation accounts for the ownership of banks, the credit to private sector and possible controls over interest rates; business regulation accounts for administrative requirements and bureaucratic costs, bribes and favoritism, licensing restrictions, cost of tax compliance; labour market regulation includes hiring and firing rules, compulsory minimum wages, centralized collective bargaining, and hours regulation. As all these measures consider freedom from regulation, one could interpret the estimated coefficients as freedom from rentseeking behaviour, on the premise that less regulation will reduce available rents according to standard public choice arguments (Tullock, 1967). Only coefficients for credit market regulations and business regulations are positive, but just the latter is also statistically significant: less regulation seems to be associated with more redistribution, precisely as one would expect. On the contrary, labour market regulation coefficient is negative, albeit not statistically significant. This hints at the fact that more regulation reasonably implies a more equal wage structure and, in turn, wage compression requires less redistribution (e.g., Barth and Moene, 2012). In this sense, redistribution is obtained ex ante by the government, an issue that we discuss in greater details below.

\subsubsection{The instruments and resources for redistribution}

Political and economic institutions constitute the supply side of redistribution. Their interaction with demand side variables will produce equilibrium policies implemented by the government, using instruments and resources for redistributing income. However, differently from economic and political institutions, which change only slowly, policies can be clearly endogenous to the level of inequality. Table 8 considers the main instruments for redistribution, looking at both the revenue and the spending side of the public budget. As for the revenue side, we look at the role of the personal income tax (PIT) using two variables: the top marginal tax rate and the importance of the income tax revenues over total revenues. Information on tax rates are provided by the Fraser Institute and have to be considered as 'freedom from taxation', meaning greater freedom in countries where top rates are lower. 
Consistently with this reading, the coefficient turns out to be negative and significant, whereas the composition of revenues does not seem to affect redistribution. Hence, it is not the PIT per se, but how the PIT treats the more affluent citizens that matters for redistribution, confirming previous suggestive evidence in, Alvaredo et al. (2013), for instance. Turning to the composition of public spending, health expenditures have a positive and significant coefficient, but only in the LIS sample; whereas public transfers, basically public pensions, are significant in the SWIID sample. This is expected since the LIS market income already includes incomes from pensions, as discussed in previous section 2. Interestingly, the role of the ex ante Gini coefficient, and the share of public spending out of GDP remain positive and statistically significant across almost all specifications.

Table 9 looks at resources for redistribution. GDP turns out to be positive and significant, at least in the SWIID sample, meaning that richer countries (with more resources that can be redistributed) redistribute more, a result consistent with analysis in, e.g., Ravallion (2010). Results on debt and deficit are less clear-cut. As for debt, the coefficient is almost always negative, albeit statistically significant in just one case. On the contrary, the coefficient on deficit is significant and positive in the SWIID more complete sample. One could argue that standard Keynesian arguments will help redistribution in the short run, but cumulating debt will require tighter fiscal policies in the long run, with a consequent negative impact on redistribution.

\subsubsection{Ex ante redistribution?}

Finally, we investigate whether demand and supply side variables are correlated with the ex ante distribution of income, to understand whether there is a role for government intervention in affecting market incomes. According to the Okun's leaky bucket story, working on ex ante (re-)distribution will avoid all efficiency losses implied by the ex post redistribution. In terms of policies, this means that government will intervene on the causes of inequality, instead of curing the symptoms downstream. One striking example of this approach is the blend of policies put forward in Scandinavian countries: according to Barth and Moene (2012), the higher employment rates are the reward for a more equal (ex ante) wage structure, all of which depends on the generosity of the welfare state that fuels participation in the labour market. To this end, we estimate a model similar to that in Eq.[1], where we replace the redistribution indicator GINI_DIFF with the Gini 
coefficient on market incomes. Results are not reported here for the sake of brevity, but they are available upon request: strikingly, most of the coefficients are not statistically significant, suggesting that both demand side and supply side variables are not associated with a more equal ex ante distribution. We do find some evidence of a positive correlation between the top marginal income tax rate, the share of income tax revenue and the share of public spending over GDP with the ex-ante Gini coefficient. Causation, however, is likely to run from the more unequal ex ante distribution to the instruments available to government, via demand for redistribution. These findings are somewhat in line with Barth and Moene (2012), who show only a weak association between bargaining coordination and labour market outcomes. If political and economic institutions are not correlated with the distribution of market income, it is to globalization and/or to skill-biased technical change that one should look at as the main common culprits for the evolution of ex ante inequality (e.g., Bourguignon, 2015).

\section{Conclusions}

In this paper we have examined empirically to what extent political institutions explain different performances in income redistribution in countries that vary in terms of size of the public sector, tax systems, and governance. In line with the original idea by Okun (1975), namely that redistribution from rich to poor is carried out through a 'leaky bucket', we use the difference between the ex ante and the ex post Gini indices of income inequality as the measure of the degree of redistribution achieved in different countries. Contrary to the simple approaches of both the 'redistribution' theory and the 'median voter' theory, our estimates provide support to the claim that political and economic institutions - i.e., the supply side of redistribution - are correlated with the degree of redistribution. In particular, our results show that ceteris paribus parliamentary systems and proportional electoral rules are associated with a greater degree of redistribution; corruption and regulation, on the contrary, reduce the redistribution that could be achieved. In terms of instruments for redistribution, the analysis suggests the importance of taxing the richest classes in the society via high tax rates on top incomes. Moreover, we find a positive and statistically significant correlation of public spending with the degree of redistribution, whereas the composition of public spending does not seem to matter at this aggregate level. 
As many political institutions in fact determine the differences in the degree of redistribution across countries, our results cast a number of doubts on previous cross-country studies that analyze the relationship between redistribution, inequality, and economic efficiency. In a policy perspective, to the extent that public spending positively affects redistribution, and considering that political factors can either help (as is the case of parliamentary systems) or counterbalance (as is the case of corruption) the impact of spending, there are no simple policy recipes to enhance efficiency and/or equity that are applicable in all countries; on the contrary, redistributive policies must be declined taking into account the peculiar institutions that characterize each country. A schoolbook example is the central tenet of marketoriented reforms to cut back Welfare State spending in order to promote growth. In a country like Italy, where the level of corruption is perceived to be high, cutting public spending can probably increase both the amount of redistribution and economic growth. On the contrary, in a country such as Norway, virtually unaffected by corruption, the same recipe would be probably detrimental to both redistribution and growth.

Finally, one must recognize that studies on income redistribution suffer from lack of data for cross-country analysis. Given the importance of the matter, it is surprising how poor is our knowledge of the degree of redistribution achieved by different countries, and how few are the governments around the world which collect the relevant information to map this phenomenon. Additional efforts to make more information available in the future are most welcome.

\section{References}

Acemoglu D., S. Naidu, P. Restrepo, J. A. Robinson (2015). Democracy, Redistribution, and Inequality. In: Handbook of Income Distribution Volume 2, 1885-1966.

Acemoglu, D., and Robinson J.A. (2015). The Rise and Decline of General Laws of Capitalism. Journal of Economic Perspectives 29 (1): 3-28.

Aidt, T., and Franck, R. (2015). Democratization Under the Threat of Revolution: Evidence From the Great Reform Act of 1832. Econometrica 83 (2): 505-547. 
Alesina, A. and Giuliano, P. (2011). Preferences for redistribution. In Handbook of social economics.

Alesina, A. and Glaeser, E. (2004). Fighting Poverty in the US and Europe: A World of Difference. Oxford: Oxford University Press.

Alvaredo F., Atkinson, A. B., Piketty, T. and Saez, E. (2013). The top 1\% in international and historical perspective. Journal of Economic Perspectives, 27(3): 3-20.

Atkinson, A. B., Piketty, T. and Saez, E. (2011). Top Incomes in the long run of history. Journal of Economic Literature, 49(1): 3-71.

Austen-Smith, D. (2000). Redistributing income under proportional representation. Journal of Political Economy, 108 (6): 1235-1269.

Ballard, C. L. (1988). The marginal efficiency cost of redistribution. American Economic Review, 78: 1019-33

Barth, E., Moene, K. O. (2012). Employment as a Price or Prize of Equality: A Descriptive Analysis. Nordic Journal of Working Life Studies, 2 (2).

Becher M. (2015). Endogenous Credible Commitment and Party Competition over Redistribution under Alternative Electoral Institutions. American Journal of Political Science, forthcoming.

Beck, T., Clarke, G:, Groff, A., Keefer, P. and Walsh, P. (2001). New tools in comparative political economy: The Database of Political Institutions. World Bank Economic Review, 15(1): 165-176.

Beck, N., and Katz, J. N (1995). What to do (and not to do) with times-series crosssection data. American Political Science Review 89: 634-647.

Besley T., Coate S. (1991). Public provision of private goods and the redistribution of income. American Economic Review, 81: 979-984.

Blais, A., Massicotte, L., and Dobrzynska, A. (2003). Why is Turnout Higher in Some Countries than in Others. Elections Canada.

Boix C. (2003). Democracy and redistribution. Cambridge University Press.

Bourguignon F. (2015). The Globalization of Inequality. Princeton University Press. 
Browning, E.K. and Johnson, W. R. (1984) The trade-off between equality and efficiency. Journal of Political Economy, 92: 175-203.

Buehn, A., Schneider, F. (2012). Corruption and the shadow economy: like oil and vinegar, like water and fire? International Tax Public Finance 19: 172-194.

Danziger, S., Haveman, R. and Plotnick, R. (1981). How Income Transfer Programs Affect Work, Savings, and the Income Distribution: A Critical Review, Journal of Economic Literature 19 (3): 975-1028.

De Mello, L. and Tiongson, E. R. (2003). Income inequality and redistributive government spending. IMF Working Paper n. 14.

Feld, L. and Schnellenbach, J. (2014). Political institutions and income (re-) distribution: evidence from developed economies. Public Choice, 159(3): 435-455.

Gottschalk, P. and Smeeding, T. M. (1997). Cross-national comparisons of earnings and income inequality. Journal of Economic Literature, 35: 663-687.

Gwartney, J., Lawson, R. and Hall, J. (2015). Economic Freedom of the World: 2015 Annual Report, Fraser Institute

Hillman, A. (2009). Public finance and public policy. Responsibilities and limitations of government. II ed. Cambridge, Cambridge University Press.

Iversen, T. and Soskice, D. (2006). Electoral Institutions and the Politics of Coalitions: Why Some Democracies Redistribute More Than Others. American Political Science Review, 100: 165-181.

Larcinese, V. (2007). Voting over Redistribution and the Size of the Welfare State: The Role of Turnout. Political Studies.

Lefranc, A., Pistolesi, N. and Trannoy, A. (2008). Inequality of opportunities vs. inequality of outcomes: are Western Societies all alike? Review of Income and Wealth, 54: 513-545.

LIS (2014). Luxembourg Income Study Database [online], www.lisdatacenter.org (accessed September 2014). Luxembourg: LIS.

Mahler, V. A. and Jesuit, D. K. (2006). Fiscal redistribution in the developed countries: new insights from the Luxembourg Income Studies. Socio-Economic Review, 4: 483-511. 
Marshall, M. G., Gurr, T. R. and Jaggers, K. (2016). POLITY IV PROJECT, Political Regime Characteristics and Transitions, 1800-2015, Center for Systemic Peace.

Meltzer, A. H. and Richard, S. F. (1981). A rational theory of the size of government. Journal of Political Economy, 89: 914-927.

Meltzer, A. H. and Richard, S. F. (1983). Tests of a rational theory of the size of government. Public Choice, 41: 403-418.

Milanovic, B. (2010). Four critiques of the redistribution hypothesis: An assessment. European Journal of Political Economy, 26: 147-154.

Milanovic, B. (2000). The median-voter hypothesis, income inequality, and income redistribution: an empirical test with the required data. European Journal of Political Economy, 16: 367-410.

Musgrave, R. A. (1959). The Theory of Public Finance, New York.

Okun, A. (1975). Equality and efficiency: The big trade-off. Washington DC: Brookings Institution.

Persson, T. and Tabellini, G. (2003). The economic effect of constitutions. MIT Press.

Piketty, T. and Saez, E (2013). Income Inequality in the United States, 19131998, Quarterly Journal of Economics, 118(1): 1-39

Ravallion M. (2010). Do poorer countries have less capacity for redistribution? Journal of Globalization and Development, 1(2): 1-31.

Roemer, J. E., Aaberge, R., Colombino, U., Fritzell, J., Jenkins, S. P., and Lefranc, A. (2003). To What Extent Do Fiscal Regimes Equalize Opportunities for Income Acquisition among Citizens? Journal of Public Economics, 87: 539-65.

Romer, T. (1975). Individual welfare, majority voting and the properties of a linear income tax. Journal of Public Economics, 4: 163-85.

Scervini, F. (2012). Empirics of the median voter: democracy, redistribution and the role of the middle class. Journal of Economic Inequality, 10(4): 529-550.

Solt, F. (forthcoming). The Standardized World Income Inequality Database. Social Science Quarterly. 
Sonedda, D. and Turati, G. (2005). Winners and losers in the Italian Welfare State. A Microsimulation Analysis of income redistribution considering in-kind transfers. Giornale degli Economisti, 64(4): 423-464.

Sturm, J.-E. and De Haan, J. (2015). Income Inequality, Capitalism, and Ethnolinguistic Fractionalization. American Economic Review, 105(5): 593-97.

Tanninen, H. and Tuomala, M. (2001). Inherent inequality and the extent of redistribution in OECD countries. Tampere Economic Working Papers Net Series, n. 7, Department of Economics, University of Tampere.

Temple, J. (1999). The new growth evidence. Journal of Economic Literature XXXVII, 112-156.

Tullock, G. (1983). Economics of income redistribution. Springer.

Tullock, G. (1967). The welfare costs of tariffs, monopolies and thefts. Western Economic Journal 5(3): 224-232

World Bank (2013). World Development Indicator. The World Bank. 


\section{Tables and Figures}

Table 1: Descriptive statistics on Gini coefficients for the common set of country/years

\begin{tabular}{lccccccc}
\hline \hline & & \multicolumn{2}{c}{ LIS } & \multicolumn{2}{c}{ OECD } & \multicolumn{2}{c}{ SWIID } \\
& Obs & Mean & St.dev. & Mean & St.dev. & Mean & St.err. \\
\hline Comparable sample & & & & & & & \\
Gini coefficient (market income) & 33 & 38.5 & 4.18 & 45.8 & 5.18 & 46.0 & .84 \\
Gini coefficient (disposable income) & 42 & 31.2 & 3.30 & 30.2 & 3.42 & 29.6 & .60 \\
\hline \hline
\end{tabular}

Table 2: Summary statistics

\begin{tabular}{|c|c|c|c|c|c|c|c|c|c|c|}
\hline \multirow[b]{2}{*}{ Variable } & \multicolumn{5}{|c|}{ LIS } & \multicolumn{5}{|c|}{ SWIID } \\
\hline & $\begin{array}{l}\text { Obs } \\
(1)\end{array}$ & $\begin{array}{c}\text { Mean } \\
(2)\end{array}$ & $\begin{array}{l}\text { Std.Dev. } \\
\text { (3) }\end{array}$ & $\begin{array}{c}\text { Min } \\
(4)\end{array}$ & $\begin{array}{c}\operatorname{Max} \\
(5)\end{array}$ & $\begin{array}{l}\text { Obs } \\
(6)\end{array}$ & $\begin{array}{c}\text { Mean } \\
(7)\end{array}$ & $\begin{array}{l}\text { Std.Dev. } \\
(8)\end{array}$ & $\begin{array}{c}\text { Min } \\
(9)\end{array}$ & $\begin{array}{c}\text { Max } \\
(10)\end{array}$ \\
\hline Absolute red. & 84 & 8.05 & 3.04 & 2.1 & 18.1 & 1078 & $11.12^{*}$ & $.51^{*}$ & & \\
\hline Gini coefficient (market inc.) & 84 & 40.82 & 7.62 & 30.6 & 71.9 & 1078 & $46.03^{*}$ & $1.14^{*}$ & & \\
\hline Mean/median ratio (mkt inc) & 84 & 1.28 & .32 & 1.06 & 3.31 & & & & & \\
\hline Public exp/GDP & 84 & 32.75 & 9.16 & 13.01 & 62.71 & 1078 & 28.85 & 11.38 & 10.01 & 134.77 \\
\hline Per capita GDP (2005 US\$) & 84 & 35580.8 & 18656.4 & 2125.7 & 87772.7 & 1078 & 19744.0 & 18618.2 & 214.7 & 87772.7 \\
\hline Debt/GDP & 60 & 45.69 & 26.26 & 4.03 & 137.87 & 628 & 48.56 & 33.10 & 1.87 & 255.21 \\
\hline Deficit/GDP & 84 & 2.20 & 5.63 & -16.65 & 32.30 & 1069 & 1.89 & 4.36 & -20.3 & 32.30 \\
\hline Polity2 democracy index & 81 & 9.80 & .53 & 8 & 10 & 1054 & 8.07 & 3.63 & -7 & 10 \\
\hline Freedom from corruption & 70 & 71.49 & 20.69 & 22 & 100 & 894 & 56.27 & 25.00 & 10 & 100 \\
\hline Parliamentary system & 84 & .76 & .43 & 0 & 1 & 1057 & .56 & .50 & 0 & 1 \\
\hline Exec. orientation: right & 78 & Ref. & & & & & & & & \\
\hline Exec. orientation: centre & 78 & .09 & .29 & 0 & 1 & 858 & .17 & .38 & 0 & 1 \\
\hline Exec. orientation: left & 78 & .41 & .49 & 0 & 1 & 858 & .43 & .49 & 0 & 1 \\
\hline Proportional representation & 84 & .82 & .39 & 0 & 1 & 1046 & .83 & .38 & 0 & 1 \\
\hline $\begin{array}{l}\text { Freedom from regulation } \\
\text { index }\end{array}$ & 66 & 7.24 & .95 & 4.53 & 8.74 & 723 & 7.02 & .90 & 3.58 & 9.13 \\
\hline $\begin{array}{l}\text { Freedom from credit market } \\
\text { regulation }\end{array}$ & 66 & 8.84 & 1.21 & 4.67 & 10 & 725 & 8.69 & 1.25 & 0 & 10 \\
\hline $\begin{array}{l}\text { Freedom from labour market } \\
\text { regulation }\end{array}$ & 66 & 6.06 & 1.66 & 2.83 & 9.26 & 706 & 6.06 & 1.41 & 2.34 & 9.46 \\
\hline $\begin{array}{l}\text { Freedom from business } \\
\text { regulation }\end{array}$ & 65 & 6.84 & 1.09 & 3.61 & 8.64 & 679 & 6.33 & 1.01 & 3.03 & 9.50 \\
\hline $\begin{array}{l}\text { (Freedom from) top marginal } \\
\text { income tax rate }\end{array}$ & 66 & 5.36 & 2.14 & 1 & 10 & 718 & 6.30 & 2.47 & 0 & 10 \\
\hline Income tax / Total revenues & 84 & 31.50 & 14.28 & 6.89 & 80.63 & 1066 & 25.65 & 13.34 & .87 & 86.12 \\
\hline Public educ / Total expend & 50 & 13.29 & 2.54 & 9.30 & 20.34 & 586 & 13.71 & 3.85 & 6.70 & 28.39 \\
\hline Public educ / Total expend 2 & 66 & 17.67 & 5.34 & 9.79 & 32.96 & 779 & 17.86 & 7.35 & 1.80 & 75.38 \\
\hline $\begin{array}{l}\text { Public health expend / Total } \\
\text { expend }\end{array}$ & 72 & 14.30 & 3.25 & 5.17 & 19.03 & 901 & 12.92 & 4.26 & 3.07 & 30.61 \\
\hline Public transfers / Total expend & 83 & 60.26 & 21.99 & 15.87 & 150.46 & 1029 & 50.60 & 21.93 & .23 & 167.21 \\
\hline
\end{tabular}

*Note: these mean values are estimated, standard errors are reported in the column of the standard deviation.

Table 3: Variance decomposition of Gini coefficient, LIS

\begin{tabular}{|c|c|c|c|c|c|}
\hline Variable & & Mean & Std.Dev. & Min & Max \\
\hline \multirow{3}{*}{$\begin{array}{l}\text { Gini coefficient } \\
\text { (market inc.) }\end{array}$} & overall & 40.82 & 7.62 & 30.6 & 71.9 \\
\hline & between & & 8.93 & 32.37 & 71.2 \\
\hline & within & & 1.43 & 36.67 & 44.34 \\
\hline \multirow[t]{3}{*}{ Absolute red. } & overall & 8.05 & 3.04 & 2.1 & 18.1 \\
\hline & between & & 2.94 & 2.27 & 14.13 \\
\hline & within & & 1.07 & 5.31 & 12.01 \\
\hline
\end{tabular}


Table 4: Comparison across different samples and estimation methodologies

\begin{tabular}{|c|c|c|c|c|c|c|}
\hline Dep.var.: Absolute redistribution & $\begin{array}{l}\text { LIS } \\
\mathrm{b} / \mathrm{se}\end{array}$ & $\begin{array}{l}\text { SWIID } \\
\text { b/se }\end{array}$ & $\begin{array}{c}\text { SWIID } \\
\text { b/se }\end{array}$ & $\begin{array}{c}\text { OECD } \\
\text { b/se }\end{array}$ & $\begin{array}{l}\text { LIS } \\
\text { b/se }\end{array}$ & $\begin{array}{l}\text { SWIID } \\
\text { b/se }\end{array}$ \\
\hline Gini coeff. (market income) & 0.690 & 0.806 & 0.439 & 0.498 & 0.267 & 0.365 \\
\hline Clustered s.e. & $(0.101)^{* * *}$ & $(0.110)^{* * *}$ & $(0.080)^{* * *}$ & $(0.114)^{* * *}$ & $(0.112)^{* *}$ & $(0.128)^{* * *}$ \\
\hline Non clustered s.e. & $(0.053)^{* * *}$ & $(0.054)^{* * *}$ & $(0.041)^{* * *}$ & $(0.050)^{1 * * *}$ & $(0.053)^{* * *}$ & $(0.068)^{* * *}$ \\
\hline Mean/median ratio (market income) & -25.469 & -29.406 & . & . & . & . \\
\hline Clustered s.e. & $(3.178)^{* * *}$ & $(3.304)^{* * *}$ & $\cdot$ & . & & . \\
\hline Non clustered s.e. & $(2.236)^{* * *}$ & $(2.183)^{* * *}$ & & & & \\
\hline & 34.868 & 45.747 & -18.328 & -9.781 & -14.725 & -16.087 \\
\hline Constant & $(7.159)^{* * *}$ & $(7.953)^{* * *}$ & $(4.912)^{* * *}$ & $(4.728)^{* *}$ & $(7.952)^{*}$ & $(8.718)^{*}$ \\
\hline Non clustered s.e. & $(5.306)^{* * *}$ & $(5.650)^{* * *}$ & $(2.180)^{* * *}$ & $(2.154)^{* * *}$ & $(4.301)^{* * *}$ & $(5.255)^{* * *}$ \\
\hline Obs & 134 & 134 & 2030 & 213 & 134 & 134 \\
\hline Countries & 30 & 30 & 73 & 31 & 30 & 30 \\
\hline r2 & 0.639 & . & . & 0.641 & 0.267 & . \\
\hline Time fixed effects & No & No & Yes & No & No & No \\
\hline Region fixed effects & Yes & Yes & Yes & Yes & Yes & Yes \\
\hline Dep.var.: Absolute redistribution & $\begin{array}{l}\text { LIS } \\
\mathrm{b} / \mathrm{se}\end{array}$ & $\begin{array}{c}\text { SWIID } \\
\text { b/se }\end{array}$ & $\begin{array}{l}\text { SWIID } \\
\mathrm{b} / \mathrm{se}\end{array}$ & $\begin{array}{c}\text { OECD } \\
\mathrm{b} / \mathrm{se}\end{array}$ & $\begin{array}{l}\text { LIS } \\
\mathrm{b} / \mathrm{se}\end{array}$ & $\begin{array}{c}\text { SWIID } \\
\text { b/se }\end{array}$ \\
\hline Gini coeff. (market income) & 0.469 & 0.834 & 0.329 & 0.694 & 0.086 & 0.339 \\
\hline Clustered s.e. & $(0.106)^{* * *}$ & $(0.108)^{* * *}$ & $(0.100)^{* * *}$ & $(0.104)^{* * *}$ & $(0.098)$ & $(0.222)^{\wedge}$ \\
\hline Non clustered s.e. & $(0.056)^{* * *}$ & $(0.063)^{* * *}$ & $(0.055)^{* * *}$ & $(0.054)^{* * *}$ & $(0.041)^{* *}$ & $(0.072)^{* * *}$ \\
\hline Mean/median ratio (market income) & -12.194 & -18.378 & . & . & . & . \\
\hline Clustered s.e. & $(3.364)^{* * *}$ & $(4.833)^{* * *}$ & . & . & . & $\cdot$ \\
\hline Non clustered s.e. & $(1.445)^{* * *}$ & $(1.498)^{* * *}$ & . & . & . & . \\
\hline \multirow[t]{3}{*}{ Constant } & 4.41 & 0.375 & -2.077 & -15.317 & 4.615 & 0.176 \\
\hline & $(2.952)^{\wedge}$ & $(4.964)$ & $(4.294)$ & $(4.961)^{* * *}$ & $(3.876)$ & $(10.231)$ \\
\hline & $(1.357)^{* * *}$ & $(2.247)$ & $(2.727)$ & $(2.519)^{* * *}$ & $(1.679)^{* * *}$ & $(3.301)$ \\
\hline Obs & 134 & 134 & 2030 & 213 & 134 & 134 \\
\hline Countries & 30 & 30 & 73 & 31 & 30 & 30 \\
\hline $\mathrm{r} 2$ & 0.373 & & . & 0.436 & 0.032 & . \\
\hline Time fixed-effects & No & No & Yes & No & No & No \\
\hline Region fixed effects & No & No & No & No & No & No \\
\hline
\end{tabular}

Note: ${ }^{* * *} \mathrm{p}$-value $<.01,{ }^{* *} \mathrm{p}$-value $<0.05,{ }^{*} \mathrm{p}$-value $<.1, \wedge \mathrm{p}$-value $<.15$. Standard errors are clustered at country level ("clustered s.e."), or non clustered. We also compute the panel corrected standard errors, that are very similar to non clustered standard errors. Results are available from the authors. 
Table 5: Demand-side

\begin{tabular}{lcccccc}
\hline \hline Dep.var.: Absolute redistribution & $\begin{array}{c}\text { LIS } \\
\text { b/se }\end{array}$ & $\begin{array}{c}\text { SWIID } \\
\text { b/se }\end{array}$ & $\begin{array}{c}\text { SWIID } \\
\text { b/se }\end{array}$ & $\begin{array}{c}\text { LIS } \\
\text { b/se }\end{array}$ & $\begin{array}{c}\text { SWIID } \\
\text { b/se }\end{array}$ & $\begin{array}{c}\text { SWIID } \\
\text { b/se }\end{array}$ \\
\hline Gini coeff. (market income) & $0.536^{* * *}$ & $0.563^{* * *}$ & 0.261 & $0.353^{* * *}$ & $0.271^{* *}$ & -0.073 \\
& $(0.138)$ & $(0.095)$ & $(0.183)$ & $(0.078)$ & $(0.118)$ & $(0.156)$ \\
Mean/median ratio (market income) & $-17.125^{* * *}$ &. &. & $-8.481^{* * *}$ & $\cdot$ &. \\
& $(4.658)$ &. &. & $(1.715)$ &. &. \\
Public exp./GDP & $0.127^{* *}$ & 0.05 & $0.163^{* *}$ & $0.170^{* * *}$ & $0.408^{* * *}$ & $0.320^{* * *}$ \\
& $(0.053)$ & $(0.041)$ & $(0.076)$ & $(0.034)$ & $(0.104)$ & $(0.073)$ \\
Constant & $15.861^{\wedge}$ & $-28.228^{* * *}$ & -13.978 & -1.127 & $-13.186^{* *}$ & 9.876 \\
& $(10.442)$ & $(6.383)$ & $(12.070)$ & $(2.308)$ & $(5.910)$ & $(7.172)$ \\
Obs & 84 & 1078 & 84 & 84 & 1078 & 84 \\
Countries & 25 & 63 & 25 & 25 & 63 & 25 \\
r2 & 0.653 &. &. & 0.553 &. &. \\
Time fixed effects & No & Yes & No & No & Yes & No \\
Region fixed effects & Yes & Yes & Yes & No & No & No \\
\hline \hline
\end{tabular}

Note: ${ }^{* * *} \mathrm{p}$-value $<.01,{ }^{* *} \mathrm{p}$-value $<0.05,{ }^{*} \mathrm{p}$-value $<.1, \wedge \mathrm{p}$-value $<.15$. Standard errors are clustered at country level. 
Table 6: Political institutions

\begin{tabular}{lcccc}
\hline \hline & $\begin{array}{c}\text { LIS } \\
\mathrm{b} / \mathrm{se}\end{array}$ & $\begin{array}{c}\text { SWIID } \\
\mathrm{b} / \mathrm{se}\end{array}$ & $\begin{array}{c}\text { LIS } \\
\mathrm{b} / \mathrm{se}\end{array}$ & $\begin{array}{c}\text { SWIID } \\
\mathrm{b} / \mathrm{se}\end{array}$ \\
\hline Gini coeff. (market income) & $0.526^{* * *}$ & $0.522^{* * *}$ & $0.433^{* * *}$ & $0.234^{* * *}$ \\
& $(0.151)$ & $(0.104)$ & $(0.117)$ & $(0.085)$ \\
Mean/median ratio (market income) & -11.905 &. & $-7.589^{* * *}$ &. \\
& $(8.369)$ &. & $(1.967)$ &. \\
Public exp./GDP & $0.083^{*}$ & 0.001 & $0.082^{* *}$ & 0.136 \\
& $(0.046)$ & $(0.027)$ & $(0.031)$ & $(0.094)$ \\
Polity2 democracy index & 1.099 & -0.258 & 1.077 & -0.009 \\
& $(1.567)$ & $(0.282)$ & $(1.039)$ & $(0.353)$ \\
Freedom from corruption & $0.048^{*}$ & $0.129^{* * *}$ & $0.057^{* *}$ & $0.116^{* * *}$ \\
& $(0.028)$ & $(0.022)$ & $(0.022)$ & $(0.035)$ \\
Presidential system & $-1.791^{\wedge}$ & 0.980 & 0.884 & $-6.561^{* *}$ \\
& $(1.172)$ & $(2.044)$ & $(2.016)$ & $(2.606)$ \\
Exec. Right & -0.494 & 0.196 & -0.630 & -1.097 \\
Exec. Left & $(1.344)$ & $(0.718)$ & $(1.429)$ & $(0.904)$ \\
Majoritarian repr. & -0.247 & 0.903 & -0.143 & -0.550 \\
& $(1.354)$ & $(0.917)$ & $(1.458)$ & $(1.245)$ \\
Exec. right X Presidential system & $-2.855^{*}$ & -1.305 & $-2.508^{*}$ & -1.294 \\
& $(1.578)$ & $(3.255)$ & $(1.329)$ & $(4.037)$ \\
Exec. left X Presidential system & 1.212 & -0.753 & -1.404 & 0.060 \\
& $(1.683)$ & $(1.386)$ & $(2.697)$ & $(1.429)$ \\
Exec. right X Majoritarian repr. & & -1.955 & -2.499 & -0.707 \\
& & $(1.718)$ & $(1.964)$ & $(1.699)$ \\
Exec. left X Majoritarian repr. & -0.240 & 1.754 & 0.116 & 0.642 \\
Constant & $(1.641)$ & $(3.403)$ & $(1.577)$ & $(4.292)$ \\
Obs & & -0.923 & & -0.333 \\
r2 & & $(3.346)$ & & $(4.103)$ \\
Time fixed effects & -8.529 & $-32.473^{* * *}$ & -16.110 & -7.424 \\
Region fixed effects & $(32.941)$ & $(7.833)$ & $(11.399)$ & $(5.630)$ \\
\hline \hline & 63 & 682 & 63 & 682 \\
& 23 & 53 & 23 & 53 \\
& 0.765 & $\cdot$ & 0.752 &. \\
& $\mathrm{No}$ & Yes & No & Yes \\
& Yes & Yes & No & No \\
\hline
\end{tabular}

Note: ${ }^{* *} \mathrm{p}$-value $\overline{\overline{<.01},{ }^{* *} \mathrm{p} \text {-value }<0.05,^{*} \mathrm{p} \text {-value }<.1,{ }^{\wedge} \mathrm{p} \text {-value }<.15 \text {. Standard error are clustered }}$ at country level. 
Table 7: Rent seeking

\begin{tabular}{lcccc}
\hline \hline & LIS & SWIID & LIS & $\begin{array}{c}\text { SWIID } \\
\mathrm{b} / \mathrm{se}\end{array}$ \\
\hline Gini coeff. (market income) & $0.534^{* * *}$ & $0.516^{* * *}$ & $0.394^{* * *}$ & $0.281^{* *}$ \\
& $(0.153)$ & $(0.098)$ & $(0.086)$ & $(0.130)$ \\
Mean/median ratio (market income) & $-13.940^{* *}$ &. & $-8.508^{* * *}$ &. \\
& $(5.834)$ &. & $(1.547)$ &. \\
Public exp./GDP & $0.128^{* *}$ & $0.059^{\wedge}$ & $0.164^{* * *}$ & $0.422^{* * *}$ \\
& $(0.055)$ & $(0.039)$ & $(0.044)$ & $(0.083)$ \\
Freedom from credit market regulation & 0.125 & 0.117 & 0.27 & 0.677 \\
& $(0.293)$ & $(0.305)$ & $(0.286)$ & $(0.475)$ \\
Freedom from labour market regulation & -0.21 & -0.047 & -0.205 & -0.136 \\
Freedom from business regulation & $(0.221)$ & $(0.437)$ & $(0.208)$ & $(0.499)$ \\
& 0.62 & $1.325^{* * *}$ & $0.862^{* *}$ & $1.995^{* * *}$ \\
& $(0.426)$ & $(0.474)$ & $(0.339)$ & $(0.740)$ \\
Constant & & & & - \\
Obs & 2.142 & $-34.325^{* * *}$ & $-9.517^{*}$ & $30.669^{* * *}$ \\
Countries & $(16.595)$ & $(8.435)$ & $(4.757)$ & $(7.833)$ \\
r2 & 65 & 679 & 65 & 679 \\
Region fixed effects & 24 & 60 & 24 & 60 \\
\hline \hline
\end{tabular}

Note: ${ }^{* * *} \mathrm{p}$-value $<.01,{ }^{* *} \mathrm{p}$-value $<0.05,{ }^{*} \mathrm{p}$-value $<.1,{ }^{\wedge} \mathrm{p}$-value $<.15$. Standard error are clustered at country level. 
Table 8: Instruments for redistribution

\begin{tabular}{lcccc}
\hline \hline & $\begin{array}{c}\text { LIS } \\
\mathrm{b} / \mathrm{se}\end{array}$ & $\begin{array}{c}\text { SWIID } \\
\mathrm{b} / \mathrm{se}\end{array}$ & $\begin{array}{c}\text { LIS } \\
\mathrm{b} / \mathrm{se}\end{array}$ & $\begin{array}{c}\text { SWIID } \\
\mathrm{b} / \mathrm{se}\end{array}$ \\
\hline Gini coeff. (market income) & $0.342^{*}$ & $0.565^{* * *}$ & $0.319^{* *}$ & $0.298^{* *}$ \\
& $(0.169)$ & $(0.101)$ & $(0.112)$ & $(0.147)$ \\
Mean/median ratio (market income) & -3.972 & $\cdot$ & $-6.800^{* * *}$ & $\cdot$ \\
& $(6.004)$ & $\cdot$ & $(1.734)$ &. \\
Public exp./GDP & $0.180^{* *}$ & 0.046 & $0.176^{* * *}$ & $0.270^{* *}$ \\
& $(0.068)$ & $(0.042)$ & $(0.055)$ & $(0.102)$ \\
(Freedom from) top marginal income tax rate & $-0.460^{* *}$ & $-0.614^{* * *}$ & $-0.536^{* * *}$ & $-1.154^{* * *}$ \\
& $(0.208)$ & $(0.271)$ & $(0.170)$ & $(0.355)$ \\
Income tax / Total revenues & -0.005 & 0.002 & -0.021 & -0.058 \\
& $(0.046)$ & $(0.053)$ & $(0.032)$ & $(0.052)$ \\
Public education expend / Total expend & 0.068 & 0.049 & 0.012 & 0.094 \\
& $(0.092)$ & $(0.053)$ & $(0.086)$ & $(0.069)$ \\
Public health expend / Total expend & 0.226 & 0.122 & $0.280^{* *}$ & 0.135 \\
& $(0.168)$ & $(0.104)$ & $(0.122)$ & $(0.125)$ \\
Public transfers / Total expend & 0.01 & 0.03 & 0.01 & $0.101^{* * *}$ \\
& $(0.011)$ & $(0.022)$ & $(0.011)$ & $(0.028)$ \\
Constant & -15.232 & $-29.733^{* * *}$ & -3.21 & -10.275 \\
& $(18.827)$ & $(8.484)$ & $(6.100)$ & $(8.267)$ \\
Obs & 51 & 518 & 51 & 518 \\
Countries & 19 & 54 & 19 & 54 \\
r2 & 0.746 & $\cdot$ & 0.721 &. \\
Time fixed effects & No & Yes & No & Yes \\
Region fixed effects & Yes & Yes & No & No \\
\hline \hline
\end{tabular}

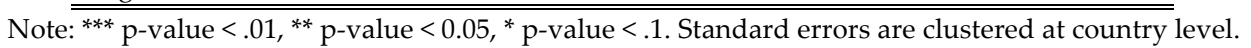


Table 9: Resources for redistribution

\begin{tabular}{lcccc}
\hline \hline Dep.var.: Absolute redistribution & $\begin{array}{c}\text { LIS } \\
\mathrm{b} / \mathrm{se}\end{array}$ & $\begin{array}{c}\text { SWIID } \\
\mathrm{b} / \mathrm{se}\end{array}$ & $\begin{array}{c}\text { LIS } \\
\mathrm{b} / \mathrm{se}\end{array}$ & $\begin{array}{c}\text { SWIID } \\
\mathrm{b} / \mathrm{se}\end{array}$ \\
\hline Gini coeff. (market income) & $0.465^{* * *}$ & $0.574^{* * *}$ & $0.426^{* * *}$ & $0.347^{* * *}$ \\
& $(0.123)$ & $(0.078)$ & $(0.077)$ & $(0.097)$ \\
Mean/median ratio (market income) & $-10.162^{*}$ & $\cdot$ & $-7.878^{* * *}$ & $\cdot$ \\
& $(5.134)$ &. & $(1.223)$ &. \\
Public exp./GDP & $0.125^{*}$ & 0.039 & $0.158^{* * *}$ & $0.270^{* * *}$ \\
& $(0.063)$ & $(0.050)$ & $(0.037)$ & $(0.092)$ \\
GDP (2005 US\$) & 0 & $0.000^{* * *}$ & 0 & $0.000^{* * *}$ \\
& $(0.000)$ & $(0.000)$ & $(0.000)$ & $(0.000)$ \\
Debt/GDP & -0.004 & 0.001 & -0.002 & $-0.044^{* *}$ \\
& $(0.016)$ & $(0.013)$ & $(0.012)$ & $(0.021)$ \\
Deficit/GDP & 0.03 & 0.084 & 0 & $0.235^{*}$ \\
& $(0.068)$ & $(0.068)$ & $(0.046)$ & $(0.117)$ \\
Constant & 0.674 & $-31.718^{* * *}$ & $-5.330^{*}$ & $-13.693^{* * *}$ \\
& $(12.673)$ & $(5.295)$ & $(2.809)$ & $(4.785)$ \\
Obs & 60 & 624 & 60 & 624 \\
Countries & 20 & 55 & 20 & 55 \\
r2 & 0.702 &. & 0.683 &. \\
Time fixed effects & No & Yes & No & Yes \\
Region fixed effects & Yes & Yes & No & No \\
\hline \hline
\end{tabular}

Note: ${ }^{* * *} \mathrm{p}$-value $<.01,{ }^{* *} \mathrm{p}$-value $<0.05,{ }^{*} \mathrm{p}$-value $<.1, \wedge \mathrm{p}$-value $<.15$. Standard errors are clustered at country level. 
Figure 1: Comparison between different data sources of Gini coefficients for the common set of country/years

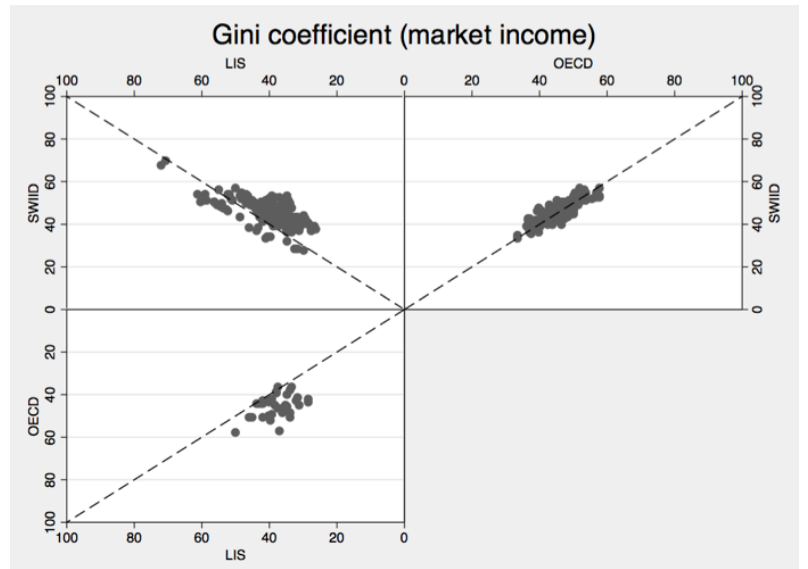

Figure 2: Comparison between different data sources of Gini coefficients for the common set of country/years

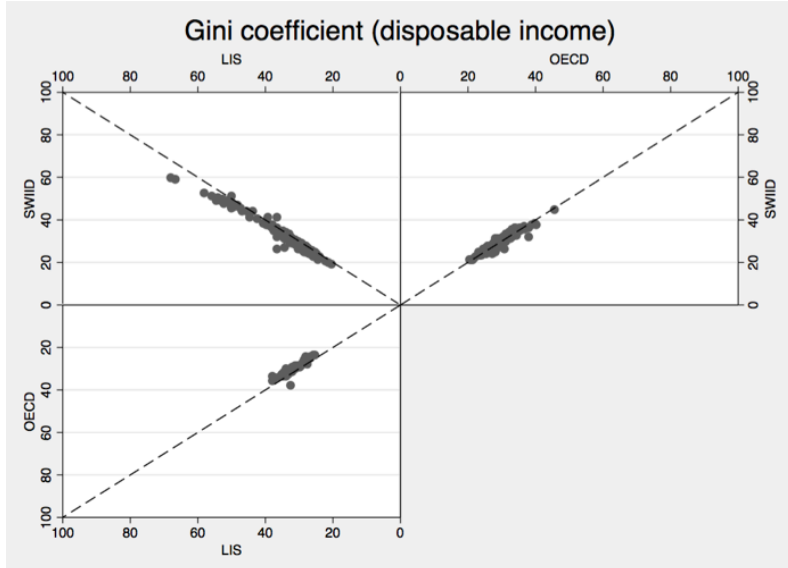

